Arab World English Journal (AWEJ) Volume 12. Number2 June 2021

DOI: https://dx.doi.org/10.24093/awej/vol12no2.17

Pp.251-267

\title{
The Place of Arabic in English as a Foreign Language University Level Classes in Jordan
}

\author{
Tamador Khalaf Abu-Snoubar \\ Department of English Language and Literature \\ Al-Balqa Applied University, Salt Faculty of Humanities \\ Jordan \\ Corresponding Author:tamadorenglish@bau.edu.jo \\ Bandar Khlil Mukattash \\ Department of English Language and Literature \\ Al-Balqa Applied University, Salt Faculty of Humanities \\ Jordan
}

Received: 2/10/2021

Accepted: 5/16/2021

Published: 6/24/2021

\section{Abstract}

Modern graduates face major challenges in the international job market where knowledge of English and other foreign languages became one of the most important requirements of a welltrained professional. Even though the demands of such candidates increase, the methodology of teaching English remains the same. Modern educators and students demand the inclusion of the first language in their English as a Foreign Language classrooms, yet still, this method is considered controversial. Previous research generated ambiguous and inconclusive findings that the current study tries to re-explore. This study aims to find out the a) students' attitude towards implementing their first language in English as a Foreign Language classes; b) how these attitudes can be related to their proficiency levels; c) the potential purposes of using the first language in the English language classrooms; and d) if teachers support using a bilingual approach in their classrooms. The current research uses a mixed-method design by applying a survey filled in by 400 students studying at Al-Balqa Applied University and semi-structured interviews with 5 instructors from the same institute to collect the data needed. The findings recognized that both students and teachers support the situational application of Arabic in the English as a Foreign Language classrooms, especially when it comes to the reading comprehension activities and introducing a new grammar topic or new vocabulary items. The use of the first language has to be proportionate to the level of students' target language proficiency, as basic English speakers require the inclusion of their first language more often than their advanced counterparts.

Keywords: bilingual approach, English as a Foreign Language, First language, mother tongue, Target Language, monolingual approach

Cite as: Abu-Snoubar, T. K., \& Mukattash, B. K. (2021). The Place of Arabic in English as a Foreign Language University Level Classes in Jordan. Arab World English Journal, 12 (2) 251267. DOI: https://dx.doi.org/10.24093/awej/vol12no2.17 


\section{Introduction}

Learning a foreign language can be a challenging task for students due to a variety of reasons. First of all, the student's initial knowledge of the Target Language (TL) might be scarce. Secondly, a student's native language could be drastically different from TL. Finally, the teaching approaches adopted in English as a Foreign Language (EFL) classes might be inaccurate and ineffective. For a very long time, the only approach used in EFL classes was a monolingual strategy that banishes the First Language (L1) during the lessons (Littlewood \&Yu, 2011). This approach is based on the idea that students learn faster and more productively when exposed to the environment of TL. While this is the main advantage of a monolingual approach, it also creates a range of drawbacks for learners. Specifically, students with little to no knowledge of TL will not be able to learn in a monolingual classroom, which creates additional stress and decreases the motivation to learn. The monolingual approach lacks flexibility and adaptability as a learning approach since educators in EFL classrooms would not be able to meet the needs of individual students (Cenoz \& Gorter, 2013). For example, if a classroom has students with several different L2 levels, teachers will not be able to adjust the curriculum and instructional materials to the needs of each learner.

However, recently educators began to acknowledge the efficacy of the bilingual teaching approach in EFL classrooms by observing the flaws of a monolingual strategy (Ull, 2020). The bilingual approach allows teachers to resort to L1 in the classroom when it is required. For a very long time, educators refused to use L1 in EFL classrooms as a result of their training and personal prejudice against the bilingual approach. For instance, a study conducted by Alrabah, Wu, Alotaibi and Aldaihani (2015) showed positive outcomes of applying a bilingual approach; yet, the study also recognized that educators were predominantly reluctant to use TL in the classroom. In a very recent and outstanding effort, Bondarenko (forthcoming) reviews the literature dealing with the relation between L1 and "cognitive authenticity." The writer concludes that there is a strong connection between the concepts of "monolingualism and naiveness-authenticity in the traditional discourse on SLA." The study supports a new blossoming "cognitive authenticity" concept that is gaining more momentum these days. This concept allows enough space for the recognition of the "sociocognitive bilingual identity" in the EFL classroom (p.12-13). Consequently, it is clear that the negative attitudes towards implementing a bilingual approach are connected to the improper teacher training that imposed incorrect perception of using L1 in the EFL classroom. This situation was pinpointed by Hanif (2020) who highlighted the importance of effectively integrating the bilingual approach in any teacher training course.

De la Campa and Nassaji (2009) conducted a study that came to the same conclusion of the teachers having a controversial perception of the bilingual approach as a result of their training. A study by Murga, Damian and Tacoaman (2018) found out that teachers have completely different attitudes towards the bilingual approach, as half of the participants used L1 regularly in the classroom, while the other half chose to completely ban L1 in their classrooms.

The main aim of the current research is to detect the attitudes of University students and educators in EFL classrooms towards the bilingual teaching approach. The objectives of the research are to find out a) students' attitude towards implementing their first language in English as a Foreign Language classes; b) how these attitudes can be related to their proficiency levels; c) 
the potential purposes of using the first language in the English language classrooms; and d) if teachers support using a bilingual approach in their classrooms.

The controversial results displayed by previous research show that there is no consensus among educators concerning the bilingual teaching approach and its benefits. This issue emerges mostly due to the teacher education that professes the benefits of a monolingual approach despite the fact that students show better results in EFL classrooms when the bilingual approach is implemented. Consequently, while it is crucial to determine the attitudes of modern teachers working in EFL classrooms to the bilingual approach, it is also important to detect the learners' perceptions and attitudes towards using L1 in EFL classrooms.

The present research uses both qualitative and quantitative methods and aims to answer the following questions.

RQ1: What is the students' attitude towards using L1 in EFL classes?

RQ2: What is the relation between the students' proficiency level and their tendency to use L1 in EFL classes?

RQ3: When do the participant students prefer L1 to be used in EFL classes?

RQ4: What are the teachers' attitudes towards using L1 in EFL classes?

Accordingly, the objective of the current study is to explore to what extent using L1 is acceptable by the two sides involved in the EFL classroom in an attempt to pave the way for the development of a more up-to-date L1 tolerant teaching approach.

\section{Literature Review}

Multiple studies worldwide contributed to the debate circulating around building more tolerance towards L1 in the EFL classroom (Fauziati, Hidayat \& Susiati 2020, Shabir 2017, Mart 2013 \& Ochi 2009). However, the problem with this bulk of literature is that it fell short of reaching decisive ends. "Results indicate that the limited use of L1 is not unnecessary and has positive effects in certain activities" is an example of how reluctant and conservative most researchers appear to be when it comes to adopting a bilingual approach (Shabir 2017).

Students' attitudes towards L1 use in the classroom are generally positive, as they tend to utilize their native language on multiple occasions in a class. Several studies recognized that students require using L1 in the classroom and prefer their native educators to teach them TL (Bateman, 2008; Hertel, 2009; Tajgozari, 2017). For instance, as it was recognized, students tend to use L1 when they need to check a new word in the dictionary or when they talk about personal things with their peers in the classroom (Galali \& Cinkara, 2017). None of the 117 participants in Tian and Hennebry's (2016) study favored an only L2 approach in their EFL classes at a Chinese university. They demonstrated that they wanted their teachers to use L1 to explain difficult topics and new vocabulary items. A sample of teachers and students explored by Hlas (2016) demonstrated the same opinion, as well. However, some studies demonstrated opposing results. Izquierdo, Marteniz, Pulido and Zuniga (2016) conducted a study to understand the reasons behind the low performance of English by Mexican students at the end of their school education. The results of the two-month video-taped observation allowed the researchers to highlight two reasons for the unsatisfying situation. The first reason was the teachers' overuse of L1 (Spanish) in the EFL classes and the second being the "lack of communicative purpose for the use of L2." Giannikas (2011) conducted a study in Greece where she encouraged the English teachers at a 
primary school to almost eliminate the presence of L1 in their classes. The findings of the experiment demonstrated that maximizing L2 in EFL classes is doable and brings better results.

The main issue that EFL classroom educators raise as a precaution when they consider the inclusion of L1 is that it would supersede TL and decrease the quality of language learning. A point of view challenged by researchers like Boustani (2019) and Afzal (2012) who explored how academic proficiency is positively affected by the use of L1 in the EFL classroom and demonstrated that its integration decreases speaking anxiety among students and produces better results in their vocabulary acquisition especially when it comes to the low-achieving students. Other benefits of using L1 in the classroom included improvement of knowledge construction in TL, facilitation of interpersonal interaction, and an increase in language efficiency (Pan \& Pan 2010). De la Fuenta and Goldsberg (2020) conducted an experimental study to see whether employing L1 in the EFL classroom brings better results than those produced in classes where only L2 is incorporated. The study that lasted for one semester employed 54 university students divided on 6 classes of elementary Spanish. The pre-test and post-test results proved that learners in the "+L1" sections improved "significantly more" than those in the "-L1" sections. This result is empowered by another challenge to the monolingual approach to L2 teaching in the form of a recent study carried out by Ali (2020). The experiment proved that L1 can positively affect the whole L2 learning process including the relation between the learners and teachers. This paper stands on two parts or studies employing university students enrolled in intermediate Spanish classes. The participants in the first study reported that they significantly rely on L1 because of their being unable to express themselves well in L2. In the second pre-test post-test part of the study, the same students were randomly divided into two groups- experimental and control. The results proved that the students in the experimental group produced more accurate answers, and as a result higher mark.

It was recognized that students' language knowledge is better supported by the use of L1 in the classroom in certain situations. Specifically, as admitted, L1 has to be used in a classroom when required by the situation rather than replacing TL completely (Almoayidi, 2018). Several studies agreed that L1 has to be applied only when it is needed like "when a student fails to understand a new term" rather than being implemented as a substitute in the EFL classroom (AlMusawi, 2014; Galali \& Cinkara, 2017). Very few studies showed that EFL educators fully approve the use of L1 in the classroom (Jadallah \& Hasan, 2014). Consequently, the use of a bilingual teaching approach is only justified when applied correctly in the classroom. In the Indonesian L1 homogeneous EFL classes, Fauziati, Hidayat and Susiati (2020) investigated through observation the ways school teachers employ L1 in their English classes as well as the reasons behind this tendency. The study reported that L1 was recognized in three patterns of "code switching: tag, inter-sentential, and intra-sentential switching." L1 is employed in several situations like giving instructions, explaining grammar, reinforcement and for classroom management. The researchers demonstrated that employing L1 in the EFL classroom is both acceptable and feasible. Using L1 for giving instructions is also proved to be useful especially in writing classes by Taniş, Sensoy and Atay (2020). De La Campa and Nassaji (2009) video recorded teaching sessions for 12 weeks of sophomore German conversation classes. After the analysis of the sessions, the researchers concluded that L1 should be implemented since it "facilitates L2 learning." 
At the same time, the reluctance of educators to utilize L1 due to several issues. First, the evidence-proved strategy claiming that students acquire TL better if they learn it in the TL environment (Parker, Heitzman, Fjerstad, Babbs \& Cohen 1995). In other words, it is believed that the more students are exposed to TL, the quicker they acquire it. Thus, the use of L1 is seen as a threat to this strategy. Second, many educators think that using a bilingual approach eliminates a challenge from the lessons, especially what concerns high-achieving students (Ortega, 2014). For instance, if educators began using L1 to attend to the needs of low-achievers or students with little TL knowledge, they might decrease the necessary level of challenge for those who have intermediate or advanced TL proficiency (in the case of the mixed classroom). Finally, opposition to using L1 is usually related to time constraints. Particularly, if students require explanation or translation of new vocabulary in L1, it could take more time and compromise the lesson plan that an educator has already developed for the students (Mahboob, 2010). Therefore, many teachers consider the bilingual approach a time-consuming strategy that prevents achieving the necessary classroom goals. However, the aforementioned issues do not take into account students' individual needs, psychological aspects connected to language learning, and their initial L1 proficiency. By ignoring these specificities of learning, many EFL teachers deny their learners a convenient and safe learning environment.

The generally ignored teachers' attitudes are explored by Kohi and Lakshmi (2020). The researchers conducted a study to investigate the attitudes of 40 EFL/ESL teachers in 12 different countries towards using L1 in their classes. The two main concerns of the study were the extent to which L1 is accepted and tolerated by EFL educators and the reasons for this employment in the EFL/ESL classrooms. The sample teachers "clearly displayed eagerness towards L1 use in their English classes. They also demonstrated that this approach is used more significantly in certain cases like translation, content explanation, class management and while dealing with the social functions of language. Macaro and Lee's (2013) sample teachers stated that the heavy "cognitive burden" placed on low and medium proficiency learners caused by using an only monolingual approach hinders their comprehension of the TL. The sample teachers that furnished a study in China by Jingxia (2010) also strongly supported the adoption of L1 in their homogeneous EFL classes.

Students use L1 during translation and writing practices, when applying thinking strategies, as well as speaking. In addition, learners tend to think in Arabic (L1) before they translate, speak, or write, which makes the elimination of L1 in an EFL classroom impossible (Boustani, 2019). Mental translation (from L1 to TL) was explored by another research that also supported the practices allowing students' occasional L1 use during writing, translation, and vocabulary acquisition (Al-Musawi, 2014). It was also discovered that teachers use L1 to improve vocabulary learning in the EFL classroom (Alvarez, 2014). Both studies confirmed that students were advocates of using L1 (both mentally and verbally) in EFL classrooms (Al-Musawi, 2014; Boustani, 2019). Despite the fear of many educators that L1 use could potentially decrease the challenge for students, it is clear that they do not consider the specificity of L1 and TL use by the students. Unlike the popular belief, students of both basic and high levels of language proficiency use more L1 in the process of TL acquisition. While students with basic TL skills include more L1 than their more advanced counterparts (Hanáková \& Metruk, 2017). 
A positive perception of L1 implementation in the classroom shows that students benefit from this educational approach due to the specificities of language processing. For instance, it was confirmed that the brain processes two or more languages in parallel (Ellis \& Natsukos, 2014: 235 - 240). This means that creating the so-called immersion classrooms where students are surrounded by TL can be unnecessary. Particularly, if students were capable of learning TL alongside their already-formed knowledge of L1, the use of L1 would not interfere with their TL acquisition. It was found that L1 is applied in the classroom as a scaffolding strategy in specific situations when a better explanation of the terms or phenomena is required (Bhooth, Azman \& Ismail, 2014; Shabir, 2017). L1 is used in the classroom to enhance TL acquisition (Lopes \& Cecilia, 2019). According to two other studies, students' inability to use L1 in their EFL classes prevents them from using an invaluable cognitive tool (Moeller, 2013; Arenas-Iglesias, 2016). Banning the inclusion of L1 in the EFL classroom practices is a myth, as the bilingual approach allows students to notice the similarities and differences between L1 and TL, especially in wordto-word translation assignments (Laufer \& Girsai, 2008). Students tend to learn TL by following individual strategies and using L1 as a tool. Even though the bilingual approach depends on evidence and testimonials of students' learning in EFL classrooms, the application of L1 remains scarce.

\section{Methodology}

Research Design

Since the present research aims at detecting the attitudes of EFL learners and educators toward the bilingual teaching approach, the researchers decided that the study would benefit from a mixed research design. This type of research design allows researchers to generate both empirical and conceptual evidence to answer the questions. In the current case, using a mixed design allowed the researcher to combine the findings retrieved from two groups of the sample (students and educators) to fill the gap in the literature dealing with this issue. Mixed design helped the researchers to highlight the students' attitudes towards the bilingual approach and the educators' experience in using this approach in EFL classrooms. To fulfill the main aim of the study, the researchers found it crucial to consider both stakeholder groups (learners and educators), as their experiences in the EFL classroom differ dramatically. Specifically, while the quantitative tool was used to detect the learners' attitudes and preferences, the qualitative design lent a helping hand in explaining why or why not the bilingual approach is helpful in the EFL classroom from the educators' view.

\section{Participants}

As noticed earlier, the study recruited two groups for the sample. For the quantitative design, the researcher randomly recruited 400 university students currently studying TL (English) in EFL classrooms with Arabic as their L1. The criteria for inclusion in this sample were the following: being a student at Al-Balqa Applied University (regardless of their majors), having Arabic as their L1, and willingness to participate. An announcement was placed on the students' board with the researcher's contacts. Participants who decided to contact the researcher, received brief information about the study, a sample of the consent form, a sample of the questionnaire, and a list of the rights and responsibilities of the participation. The university EFL educators who formed the second sample were recruited depending on purposive sampling. Five educators eventually took part in the research. Criteria for inclusion were the following: being employed as an educator in the Department of English Language and Literature at Al-Balqa Applied 
University in the first semester of the academic year 2019-2020, the experience of being an EFL teacher for at least five years, and willingness to take part in the research. This group of respondents was recruited face-to-face by approaching each educator personally. This group of participants received the same list of documents except for the questionnaire.

\section{Research Instruments}

Quantitative data was collected by the original survey that was elaborated by the researcher and completed by the participant students. The questionnaire for the survey included 12 items (Appendix A), which included the questions on the topic of research in addition to some biographic data (e.g. level of TL proficiency, age, gender). The scaling questionnaire has 5-point Likert scale ("strongly disagree" - 1; "disagree" - 2; "undecided" - 3; "agree" - 4; "strongly agree" - 5). The surveys were supposed to be filled out by 417 students, but 400 samples were retrieved through electronic mail. This part of the research took about ten working days to complete.

Qualitative data was collected with the help of semi-structured interviews. This type of interview assists researchers in conducting a comprehensive investigation of a specific question. Semi-structured interviews were selected as the data collection method, as the researcher has to cover a topic that might have controversial answers. It is also possible that educators have more knowledge about the topic that the researcher did not take into account. In other words, it was important to conduct as full and as comprehensive research of the bilingual approach as possible. Interviews were conducted at a previously planned time convenient for the interviewees. Each interview lasted for about 30 minutes. Interviews were tape-recorded and transcribed.

\section{Data Analysis}

Quantitative data was analyzed by using the SPSS statistical package in Microsoft Excel. The researcher used descriptive statistics to determine the importance of a bilingual approach (using L1 in the classroom) for the students in the EFL classroom. In addition, the study applied correlational analysis between the TL proficiency of participants and the attitude towards using L1 in the classroom. Qualitative information was analyzed manually by using simple coding. After transcription of data, the researcher retrieved several codes, descriptions, and examples. Interpretation of coded information followed the analysis.

\section{Reliability and Validity}

The study recruited a relatively large number of participants that ensured the generalizability of the results. To decrease sample bias, participants were randomly selected among the target audience by considering the homogeneity of the sample. Validity was also ensured by targeting the phenomenon that the study aimed at measuring, namely, the significance of a bilingual teaching approach for students. Reliability was ensured by using enough questions to evaluate the competence of the participants. Specifically, questions in semi-structured interviews were the same or similar to prevent any inconsistencies. In order to validate the new original survey, it was reviewed by a group of experts. After their review, several aspects of the questionnaire were revised. The reliability of the quantitative tool was ensured by calculating Chronbach's alpha (Appendix C). 


\section{Ethics}

Participation in the survey and interviews was voluntary and anonymous. Participants were not allowed to discuss their answers with other people and other respondents. Each respondent had the ability to refuse to participate or withdraw her/his data from the research at any stage of the process. Personal data was retrieved from participants except for their age, gender, level of TL proficiency (students) and years of experience (teachers). This information was critical for the research and added credibility to the results. Sensitive topics were not addressed during the study. However, teachers had a chance to provide suggestions, recommend changes, and criticize the current system of teaching that could have potentially affected their careers. Thus, the researcher decided to mark participating educators with a letter to conceal their identities.

\section{Limitations of the Study}

The study has certain limitations. Specifically, the researchers recruited a small number of interviewees, which could affect the chances to generalize the results. Due to the time constraints and limited number of highly trained educators, the number was limited to five interviewees. Due to same time constraints, it was impossible to develop a larger and more comprehensive survey that would control confounding variables and eliminate potential bias.

\section{Results}

\section{Quantitative Study}

\section{Biographic Data}

The majority of the student respondents represent the younger age group (18-20) due to the typical age of the students in the university as shown in Figure 1.

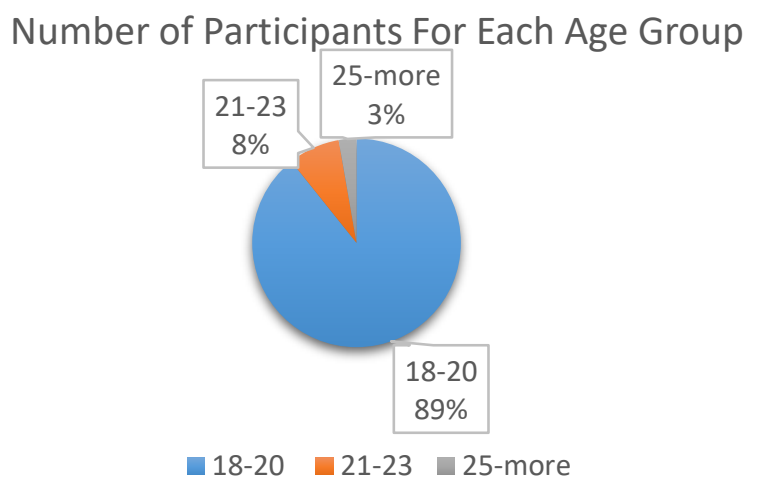

Figure 1. Characteristics of the study sample in terms of age.

Figure 2 reveals that the majority of the participants were females (63\%) and the rest were males $(37 \%)$.

\section{Gender}

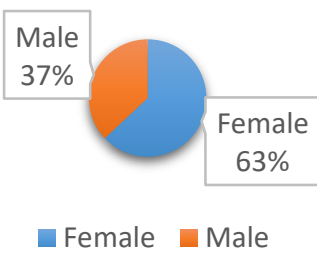

Figure 2. Characteristics of the study sample in terms of participants' gender. 
Figure 3 indicates that the majority of the respondents had basic level of English (53.8\%), lower number of participants had independent level of English (38.8\%), and the rest of the group had a proficiency level of $(7.5 \%)$.

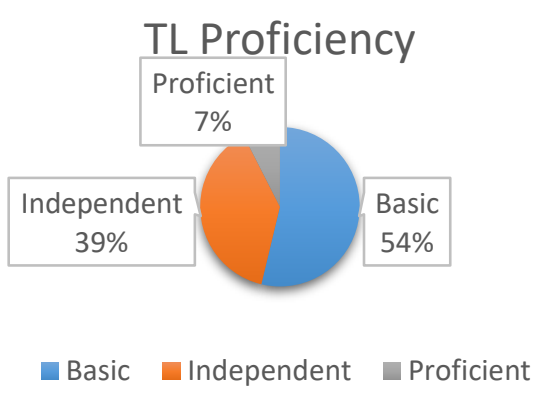

Figure 3. Characteristics of the study sample in terms of proficiency level of English.

RQ 1: What are the students' attitudes towards using L1 in EFL classes?

Table 1. Participants' attitudes towards using L1 in EFL classes.

\begin{tabular}{|l|l|l|l|l|}
\hline & Questions & $\begin{array}{l}\text { Mean } \\
\text { (M) }\end{array}$ & $\begin{array}{l}\text { Standard } \\
\text { Deviation } \\
\text { (SD) }\end{array}$ & Level \\
\hline 1. & $\begin{array}{l}\text { I would prefer my teacher using Arabic in my English class when } \\
\text { explaining new vocabulary. }\end{array}$ & 3.71 & 1.25 & High \\
\hline 2. & $\begin{array}{l}\text { I would prefer my teacher using some Arabic in my English class } \\
\text { when she gives instructions to the class. }\end{array}$ & 3.68 & 1.62 & High \\
\hline 3. & $\begin{array}{l}\text { I would prefer my teacher using some Arabic in my English class } \\
\text { when explaining a new grammar topic. }\end{array}$ & 4.02 & 1.01 & High \\
\hline 4. & $\begin{array}{l}\text { I would prefer my teacher allowing me to use Arabic in my English class } \\
\text { during the reading comprehension tasks. }\end{array}$ & 4.14 & 1.02 & High \\
\hline 5. & $\begin{array}{l}\text { I would prefer my teacher allowing me to use Arabic in my English class } \\
\text { while discussing errors I make in the writing assignments. }\end{array}$ & 3.56 & 1.24 & High \\
\hline 6. & $\begin{array}{l}\text { I would prefer my teacher allowing me to use Arabic in my English class } \\
\text { during the listening comprehension tasks. }\end{array}$ & 3.56 & 1.39 & High \\
\hline 7. & $\begin{array}{l}\text { I use Arabic when I have to explain something related to my English } \\
\text { lessons to my classmates. }\end{array}$ & 4.13 & 0.90 & High \\
\hline 8. & $\begin{array}{l}\text { I use Arabic during my English classroom when I exchange some } \\
\text { personal information with my classmates. }\end{array}$ & 3.25 & 1.32 & Moderate \\
\hline 9. & $\begin{array}{l}\text { I use Arabic during group work tasks since it helps us finish the task } \\
\text { faster. }\end{array}$ & 3.71 & 1.21 & High \\
\hline & Total & 3.75 & 1.21 & High \\
\hline
\end{tabular}

Table 1. illustrates that the mean average for the answers of the EFL respondents about their attitudes towards using L1 in the EFL classes was positive $(\mathrm{M}=3.75, \mathrm{~S} . \mathrm{D} .=1.21)$. The participants depicted positive attitudes towards the above items because their mean was greater than the mean of the Likert Scale. The highest mean in this table is given to item (4) "I would prefer my teacher allowing me to use Arabic in my English class during the reading comprehension tasks." $(\mathrm{M}=4.14$, S.D.=1.02). Item (8) "I use Arabic during my English classroom when I exchange some personal information with my classmates." proved to be the situation in which the respondents least preferred to use their L1 (M=3.25, S.D.=1.32). 
RQ 2: What is the relation between the students' proficiency level and their tendency to use L1 in the EFL classroom?

The correlation between the proficiency level of the participant students and tendency to use L1 in EFL classroom is shown below:

Table 2. Descriptive Statistics of the relation between the students' Proficiency Level and their tendency to use L1 in the EFL classroom

\begin{tabular}{|c|c|c|c|}
\hline & $\begin{array}{ll}\text { Basic } & \text { Level } \\
\text { Importance } & \end{array}$ & $\begin{array}{l}\text { Independent } \quad \text { Level } \\
\text { Importance }\end{array}$ & $\begin{array}{l}\text { Proficient } \\
\text { Importance }\end{array}$ \\
\hline Mean & 4,4 & 4,0 & 2,0 \\
\hline Standard Deviation & 0,624 & 0,945 & 0,907 \\
\hline Count & 215 & 154 & 30 \\
\hline
\end{tabular}

According to Table 2, the overwhelming majority of respondents with the basic level of TL admitted the importance of using L1 in an EFL classroom $(\mathrm{M}=4.46$; SD = 0.62). Participants with an average TL level also considered using L1 in the classroom as important $(M=4.09$; SD $=0.94$ ). However, those with proficient TL level acknowledged that using L1 was not important $(\mathrm{M}=2.06 ; \mathrm{SD}=0.90)$. At the same time, it is clear that the proficient students are the minority in this sample and in the University in general, which requires taking into account their point of view with caution.

RQ 3: When do the EFL students prefer L1 to be used in the classroom?

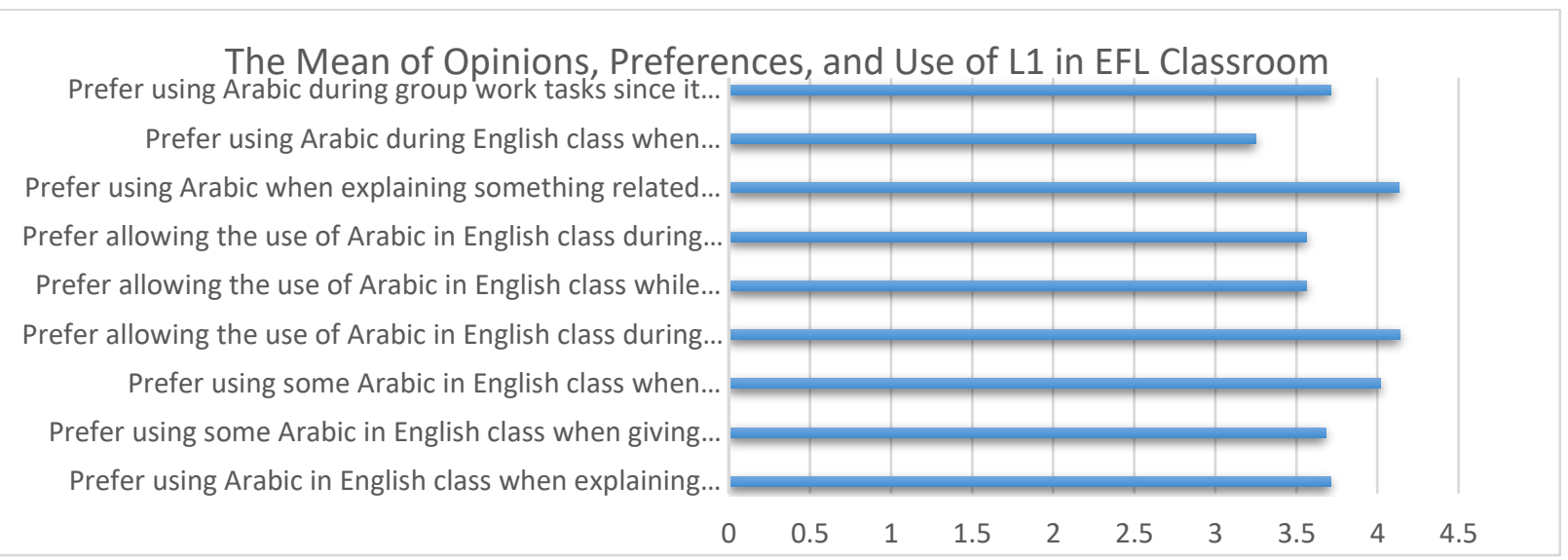

Figure 4. Descriptive statistics of opinions, preferences, and use of L1 in EFL classroom

As Figure 4 demonstrates, students especially value the use of L1 by their teacher when she/he explains a new topic $(\mathrm{M}=4.02 ; \mathrm{SD}=1.01)$ and reported an almost equal inclination towards implementing $\mathrm{L} 1 \mathrm{when}$ it comes to their reading comprehension tasks $(\mathrm{M}=4.14 ; \mathrm{SD}=1.02)$. The participants also favored the integration of L1 in the EFL classroom by their teachers in the case of introducing new vocabulary items $(M=3.71$, S.D.= 1.25). The participants also rated high penchant towards their teachers' sandwiching some L1 while giving in-class instructions $(\mathrm{M}=3.68$, S.D.= 1.62). The results reported that students would rather receive feedback on their writing tasks in L1 (M= 3.56, S.D.= 1.24) and went for getting some L1 assistance concerning listening comprehension tasks $(M=3.56$, S.D.=1.39). The participants admitted that they use L1 
more commonly when they explain something to their classmates $(\mathrm{M}=4.13$; S.D. $=0.90)$. The figures also highlight the fact that L1 is allowed space in the cases of exchanging in-class personal information $(\mathrm{M}=3.25$; S.D. $=1.32)$.

\section{Qualitative Data}

The following table includes the biographic data of the participants:

Table 2. Biographic Data of Interviewees (Educators)

\begin{tabular}{|l|l|l|l|}
\hline Participant & Age & Gender & Years of Experience \\
\hline A & 38 & Female & 10 \\
\hline B & 35 & Female & 8 \\
\hline C & 45 & Male & 20 \\
\hline D & 48 & Female & 21 \\
\hline E & 48 & Male & 20 \\
\hline
\end{tabular}

According to Table 2, all interviewees have significant experience in education and teaching students English in EFL classrooms. The majority of interviewees were females. The years of experience ranged from eight to 21 years.

RQ 4: What are the teachers' attitudes towards using L1 in EFL classes?

To answer this question, the qualitative data gained through the semi-structured interviews with the five educators were analyzed manually by using simple coding. After transcription of data, the researcher retrieved several codes, their descriptions, and examples. Interpretation of coded information is categorized in table 3 below.

Table 3. Coded Interview Data

\begin{tabular}{|l|l|l|}
\hline Code & Description & Examples \\
\hline $\begin{array}{l}\text { Monolingual } \\
\text { vs. Bilingual }\end{array}$ & $\begin{array}{l}\text { The majority of participants } \\
\text { support the use of bilingual } \\
\text { approach in the classroom. }\end{array}$ & $\begin{array}{l}\text { "I think that monolingual approach decreases the speed of } \\
\text { English acquisition in the classroom" (A); "I have used L1 in } \\
\text { my EFL classes throughout my career" (D). }\end{array}$ \\
\hline Bilingual-Use & $\begin{array}{l}\text { Teachers use L1 to explain } \\
\text { vocabulary, new terms, } \\
\text { unknown phrases, and } \\
\text { interpret the difference } \\
\text { between TL and L1. } \\
\text { it is easier to find an equivalent or explain the term in Arabic" } \\
\text { (C); "I find it quicker and more effective to use Arabic when } \\
\text { students cannot understand basic concepts in English" (B). }\end{array}$ \\
\hline $\begin{array}{l}\text { Bilingual- } \\
\text { Benefits }\end{array}$ & $\begin{array}{l}\text { Educators admit that a a } \\
\text { bilingual approach is more } \\
\text { time-efficient, adjustable, } \\
\text { and flexible in use. }\end{array}$ & $\begin{array}{l}\text { "For example, I provide printed cards to struggling students in } \\
\text { instructions, L1 should be used for it saves time and ensures } \\
\text { that all students have understood what to do. It is impossible } \\
\text { and inaccurate not to resort to Arabic in this situation" (D) }\end{array}$ \\
\hline $\begin{array}{l}\text { Bilingual- } \\
\text { Drawbacks }\end{array}$ & $\begin{array}{l}\text { Some teachers also admitted } \\
\text { certain flaws in a bilingual } \\
\text { approach }\end{array}$ & $\begin{array}{l}\text { "You have to be careful with using the native language in the } \\
\text { classroom, especially when there are proficient or gifted } \\
\text { students" (C); "Sometimes, using Arabic in the classroom for } \\
\text { a couple of students, who do not comprehend the material, is } \\
\text { counterproductive" (E). }\end{array}$ \\
\hline $\begin{array}{l}\text { Methodology- } \\
\text { Change }\end{array}$ & $\begin{array}{l}\text { Several educators admitted } \\
\text { they } \\
\text { methodology } \\
\text { adaptable }\end{array}$ & $\begin{array}{l}\text { "I can see that the methods are too standardized and I cannot } \\
\text { attend to the needs of all students" (B); "Methodology has to } \\
\text { become more applicable and realistic to match the modern } \\
\text { demands to English use" (A). }\end{array}$ \\
\hline
\end{tabular}


As Table 3 reveals, the majority of the interviewees advocate for using L1 in the EFL classroom. Several participants admitted that they used L1 during their entire career even though there are still debates that consider this approach controversial. All respondents admitted the benefits of a bilingual approach by emphasizing its adaptability, flexibility, and time-efficiency. None of the participants supported a radical banishment of L1 in the EFL classroom, yet, they admitted that the bilingual approach has to be implemented situationally. As several interviewees claimed, students prefer a bilingual approach when they struggle to understand some idioms or concepts in English as the target language (TL). The majority of participants characterized the current methodology of a total rejection of L1 as rigid and only partially effective. The recommendations to those opposed to bilingual teaching included a suggestion to consider the students' interests and consider their needs as the main priority. Overall, all interviewees supported the use of L1 in the EFL classroom.

\section{Discussion}

The study addressed the students' attitudes towards implementing L1 in there EFL classes, the spaces in the EFL classroom where L1 is preferably used, the relation between student's proficiency level and their inclination to use their mother tongue, and the teachers' attitude towards implementing L1 in the EFL classrooms. Concerning the first question "What is the students' attitude towards using L1 in EFL classes?", the statistical analysis employed proved that the sample students are strong supporters of engaging their mother tongue in the learning process taking place in their EFL classrooms $(M .=3.75$, S.D.=1.21). This result supports previous studies like Galali and Cinkara (2017), Tajgozari (2017), Hennebry's (2016) and Hlas (2016). However, this result is not in line with Izguirdo, Marteniz, Pulido and Zuniga (2016) nor Giannikas (2011). As for the second question "What is the relation between the students' proficiency level and their tendency to use L1 in EFL classes?", the results of the present study proved the presence of a positive relation between the two variables. This result supports the findings of Ali (2020), De La Fuenta and Goldsberg (2020), Boustani (2019) and Pan and Pan (2010) opposes Giannikas (2011). Coming to the third question "When do the participant students prefer L1 to be used in EFL classes?" the questionnaire developed by the researcher can form square one from which we can launch our efforts as EFL educators and methodologists to determine when and how to allow enough space for L1 in the EFL classrooms. Such surveys allow students, as well, to gain more understanding of how they learn English and elevate their self-image as successful learners who are doing nothing wrong when resorting to L1 in their efforts to learn English. As the results showed, the participant students demonstrated a high inclination for using L1 by their teachers when introducing a new grammar topic and when a new reading comprehension task is tackled. These finding support studies by Ull (2020), Galali and Cinkara (2017) though does not fully go along with Hall \& Cook (2013) and Mahmoudi and Amirkhiz (2011).

The participants' high inclination towards the use of L1 in the classroom concerning vocabulary learning supports studies by Pan and Pan (2010); Boustani (2019), Galali and Cinkara (2017), Afzal (2012) and Al-Musawi (2014). The results obtained by Krieger (2005) are not in line with the present study, however. The sample students highly valued using L1 by their teachers while giving instructions. Simplifying any in-class instructions through using an L1 explanation helps students understand the task better, do it correctly in a shorter time without 
causing their teacher to repeat the instructions more than once in English supporting Kampa and Nassaji (2009), Koucka (2007) and Taniş, Sensoy and Atay (2020).

The findings related to the use of L1 when it comes to the writing and listening tasks show an equal tendency by the participants. Students prefer to get an idea in their L1 about the listening text to be dealt with as well as to get some meanings clarified. This supports studies by Galili and Cinkara (2017) and De La Campa and Nassaji (2009). The survey results have also depicted that the participants preferred to receive feedback related to their writing tasks in their L1, supporting studies by Hidayati (2012) and Galali and Cinkara (2017).

According to the results of the present study, students with a basic proficiency level preferred using L1 in the classroom compared to proficient students, for whom the bilingual approach was not important. The current findings support the findings of previous studies and scholarly research conducted by Almoayidi (2018); Jadallah and Hasan (2014). The results partially supported the findings of Hanáková and Metruk (2017) by claiming that students with a basic proficiency level were more likely to use L1 in the classroom. The findings partially supported the claim by Alrabah et al. (2015), implying that students were especially more enthusiastic concerning the importance of a bilingual approach than educators. Results related to the fourth question "What are the teachers' attitudes towards using L1 in EFL classes?", demonstrated that teachers do integrate $\mathrm{Li}$ in their EFL classes when giving instructions, explaining difficult grammar and teaching vocabulary. Thy wanted this approach to be systematized and included in the teacher-training programs. These findings go hand in hand with Kohi and Lakshmi (2020), Macaro and Lee (2013) and Jingxia (2010). The results obtained in this study do not support the scholarly research carried out by De la Campa and Nassaji (2009) and Murga et al. (2018) demonstrating that educators are in opposition to using L1 in the EFL classrooms. In general, the results of current research supported the contemporary tendency of including L1 in the EFL classroom with both students and educators admitting its benefits. These findings imply that modern universities have to consider changing its course and allowing students as well as teachers to use L1 when needed.

\section{Conclusion}

It is important to note that the demands to the knowledge of English are increasing across the globe, which requires a more productive and effective teaching methodology. This study tried to shed brighter light the future of L1 in the EFL classroom. It studied the attitudes of learners and educators towards its integration. Both sides depicted positive attitudes towards a bilingual approach as it facilitates the learning process. The participant students in the current study preferred using L1 to secure better comprehension of difficult areas in grammar, reading texts, new vocabulary when given instructions. Students have to be able to learn English in a safe and stimulating environment that monolingual approaches can no longer guarantee. Thus, methodologists and teachers have to be more attentive to the needs of students and update their approaches and strategies accordingly.

\section{Recommendation for Future Research}

The researchers encourage educators interested in the future of L1 in English classrooms to conduct lengthy studies that compare the achievement of classes taught only in English with ones where logical space for L1 is provided. A good starting point here could be An Updated Review 
on Use of L1 in Foreign Language Classroom by Shin, Dixon and Choi (2019) and Butzkamm and Caldwell's (2009) The Building Reform: A Paradigm in Foreign Language Teaching. Other studies could dig deeper to prove whether employing L1 in the English classroom could save the teaching time and boost the students' self-esteem. Bondarenko's (forthcoming) Rethinking Authenticity in SLA from the Perspective of L2 Use can form an important and useful resource in this area.

\section{About the Author:}

Tamador Khalaf Abu-Snoubar (tamadorenglish@ bau.edu.jo). He is an Assistant Professor at Al-Balqa Applied University, Salt Faculty of Humanities, Department of English Language and Literature. He holds have a Ph. D. in TEFL and an M. A. in Comparative Literature. His major fields of interest are English Literature, Methods Teaching English Literature, Teaching English as a Foreign Language for adults and CALL. He has published eight papers in different journals. http://orcid.org/0000-0002-2689-8205

Bandar Khlil Mukattash is a lecturer at Al-Balqa Applied University/ Salt Faculty of Humanities/ Department of English Language and Literature. I have an MA in English Linguistics from Ulster University/ UK. I am mainly interested in Forensic Linguistics, Phonetics, Discourse Analysis and TEFL. http://orcid.org/0000-0002-0259-6229

\section{References}

Afzal, S. (2012). Relationship between Providing Persian Equivalents of English Adjectives and Iranian EFL Learners' Active Vocabulary. International Journal of English Linguistics, 2 (1), 231-238. https://doi.org/10.5539/ijel.v2n1p231

Almoayidi, K. (2018). The effectiveness of using L1 in second language classrooms: A controversial issue. Theory and Practice in Language Studies, 8 (4), 375-379.

Al-Musawi, N. (2014). Strategic use of translation in learning English as a foreign language (EFL) among Bahrain University students. Comprehensive Psychology, 3(4), 1-10. https://doi.org/10.2466\%2F10.03.IT.3.4

Alrabah, S., Wu, S., Alotaibi,A., Aldaihani, H.. (2015). 'English teachers' use of learners' L1 (Arabic) in college classrooms in Kuwait'. English Language Teaching, 9 (1),2-11. https://doi.org/10.5539/elt.v9n1p1

Alvarez, L. C. (2014). Selective use of the mother tongue to enhance students' English learning processes beyond the same assumptions. Profile: Issues in Teachers' Professional Development, 16(1),137151. http://dx.doi.org/10.15446/profile.v16n1.38661.

Arenas-Iglesias, L. (2016). Students' opinions about the use of L1 in an intermediate level course, (Unpublished Master's Thesis). University of St Mark and St John, U.K. http://hdl.handle.net/11117/3399

Bateman, B. (2008). Student Teachers' Attitudes and Beliefs About Using the Target Language in the Classroom. Foreign Language Annals, 41(1), 11-28. https://doi.org/10.1111/j.19449720.2008.tb03277.x

Bhooth, A., Azman, H. \& Ismail, K. (2014). The role of the L1 as a scaffolding tool in the EFL reading classroom. Procedia - Social and Behavioral Sciences, 118, 76-84. https://doi.org/10.1016/j.sbspro.2014.02.011

Bondarenko, M. (forthcoming) Rethinking Authenticity in SLA from the Perspective of L2 Use, In: W. Stadler and L. Will (Eds). Authenticity across Languages and Cultures. Themes of Identity in Foreign Language Teaching and Learning. (Chapter X) Tübingen: Narr Verlag. 
Boustani, K. (2019). The Correlation between translation equivalence, as a vocabulary learning strategy, and Tunisian EFL learners' speaking anxiety. Languages, 4(1),19-28. https://doi.org/10.3390/languages4010019

Butzkamm, W., \& Caldwell, J. (2009). The Bilingual Reform: A Paradigm Shift in Foreign Language Teaching. Tübingen: Narr Studienbücher

Cenoz, J., \& Gorter, D. (2013). Towards a Plurilingual Approach in English Language Teaching: Softening the Boundaries Between Languages. TESOL Quarterly, 4(3), 591-599. https://doi.org/10.1002/tesq.121

De La Campa, J., \& Nassaji, H. (2009). The amount, purpose, and reasons for using L1 in L2 classroom. Foreign Language Annals, 42(4), 742 - 759. https://doi.org/10.1111/j.1944-9720.2009.01052.x

Ellis, R., \& Natsuko, S. (2014). Exploring Language Pedagogy through Second Language Acquisition Research. Routledge.

Galali, A., \& Cinkara, E. (2017). The use of L1 in English as a foreign language classes: Insights from Iraqi tertiary level students. Advances in Language and Literary Studies, 8(5), 54-64.

Hall, G., \& Cook, G. (2013). Own-language Use in ELT: Exploring global practices and attitudes. London: British Council. Available at https://www.teachingenglish.org.uk/sites/teacheng/files/C448\%20 Own\%20Language\%20use\%20in\%20ELT_A4_FINAL_WEB\%20ONLY_0.pdf

Hanáková, M., \& Metruk, R. (2017) The use of L1 in the process of teaching English. Modern Journal of Language Teaching Methods, 7(8), 208-216.

Hanif, H. (2020). The role of L1 in an EFL classroom. The Language Scholar (8), 54-62

Hertel, T., \& Sunderman, G. (2009). Student Attitudes toward Native and Non-Native Language Instructors. Foreign Language Annals, 42(3), 468-475. https://doi.org/10.1111/j.19449720.2009.01031.x

Hidayati, I. (2012). Evaluating the Role of L1 in Teaching Receptive Skills and Grammar in EFL Classes.

Indonesian Journal of Applied Linguistics, 1(2), 17 -32. https://doi.org/10.17509/ijal.v1i2.82

Hlas, A. (2016). Secondary Teachers' Language Usage: Beliefs and Practices. Hispania 99 (2), 305-319. Izquierdo, J.,Martínez, V. Pulido, M., and Zúñiga, S. (2016).First and Target Language use in Public Language Education for Young Learners: Longitudinal Evidence from Mexican Secondaryschool Classrooms. System 61, 20-30.

Giannikas, C. (2011). L1in English Language Learning: A Research Study in a Greek Regional Context. International Journal of Applied Linguistics 21(3), 319-339.

Jadallah, M., \& Hasan, F. (2014). A review of some new trends in using L1 in the EFL classroom. AlQuds Open University, 1-10. https://www.semanticscholar.org/paper/A-Review-of-Some-NewTrends-in-Using-L-1-in-the-EFL-Jadallah-AlQuds/0c53b4e4b805928868ca5199983b444d3e655fb2?p2df

Jingxia, L. (2010). Teachers' code switching to the L1 in EFL Classroom. The Open Applied Linguistics Journal, 3, 10-23.

Krieger, D. (2005). Teaching ESL versus EFL: Principles and Practices. English Teaching Forum, 43 (2), 8-16.

Kohi, M. \& Lakshmi, S. (2020). Use of L1 in ESL/EFL Classroom: Multinational Teachers' Perceptions and Attitudes. International Journal of English Language \& Translation Studies. 8(3). 88-96.

Koucka, A. (2007). The Role of Mother Tongue in English Language Teaching, (Unpublished Master's thesis). University of Pardubice, Czech Republic.

Laufer, B., \& Nathan, G. (2008). Form-focused instruction in second language vocabulary learning: a case for contrastive analysis and translation. Applied Linguistics, 29(4), 694-716.

Littlewood, W., \&Yu, B. (2011). First language and target language in the foreign language classroom. Language Teaching. 44(1), 64-77 
Lopes, A., \& Ruiz- Cecilia, R. (2019). New Trends in Foreign Language Teaching: Methods, Evaluation and Innovation. Cambridge Scholars Publishing.

Mahboob, A. (2010). The NNEST Lens: Non Native English Speakers in TESOL. Cambridge: Cambridge Scholars Publishing.

Mahmoudi, L., \& Amirkhiz, S. (2011). The Use of Persian in the EFL Classroom the Case of English Teaching and Learning at Pre-University Level in Iran. English Language Teaching, 4(1), 135140. http://doi.org/10.5539/elt.v4n1p135

Macaro, E., \& Lee, J. (2013). Teacher Language Background, Codeswitching, and English-only Instruction: Does Age Make a Difference to Learners' Attitudes? TESOL Quarterly, 47(4), 717742. doi:10.1002/tesq.74.

Moeller, A., \& Roberts, A. (2013). Keeping it in the target language. Faculty Publications: Department of Teaching, Learning and Teacher Education, 178, 21-38.

Murga, B., Damian, D., Tacoaman, M. (2018). Use of L1 in English as a foreign language (EFL) learning environment. Bulletin Virtual, 7, 59-83.

Ochi, Y. (2009). The role of L1 in facilitating L2 production. Interpreting and Translation Studies, 9 , 123-140.

Ortega, L. (2014). Understanding Second Language Acquisition, Routledge.

Pan, Y., \& Pan, Y. (2010). The use of L1 in the foreign language classroom. Colombian Applied Linguistics Journal, 12 (2), 87-96. http://doi.org/ 10.14483/22487085.85

Parker, J., Hietzman, S., Fjerstad, A. (1995). Exploring the Role of Foreign Language in Immersion Education. In Eckman, F., Highland, D., Peter, W., Milcam, J., Weber, R. (Eds.), Second Language Acquisition Theory and Pedagogy (pp.235-255). New York, Routledge Taylor and Francis Group.

Shabir, M. (2017). Student- teachers' beliefs on the use of L1 in EFL classroom: A global perspective. English Language Teaching, 10(4), 45-52. http://doi.org/10.5539/elt.v10n4p45

Tajgozari, M. (2017). Factors contributing to the use of L1 in English classrooms: Listening to the voice of teachers and students in Iranian institutes. International Journal of Research in English Education, 2(2), 63-75. http://doi.org/10.18869/acadpub.ijree.2.2.63

Taniş, A., Şensoy, H., \& Atay, D. (2020). The effects of L1 use and dialogic instruction on EFL writing. Eurasian Journal of Applied Linguistics, 6(1), 1-21. http://doi.org/10.32601/ejal.710178

Tian, L., and Hennebry, M. (2016). Chinese Learners' Perceptions Towards Teachers' Language Use in Lexical Explanations: A Comparison Between Chinese-only and English-only Instructions. System 63: 77-88.

Ull, A. (2020). A Plurilingual Approach to English Language Teaching from an Ecological Perspective: An international comparative study, (Unpublished Doctoral Dissertation). Universitat Jaume I, Spain. Available at https://www.tdx.cat/handle/10803/669334\#page=1,

\section{Part I: Biographic Information}

\section{Appendix A}

\section{Survey Questionnaire}

1. Please, state your gender: male female

2. Please, state your age:

3. Please, state your level of English proficiency: basic independent proficient

\section{Part II: Opinions on Bilingual Teaching Approach}

State your opinion of the statements by evaluating them according to the following scale:

"strongly disagree" "disagree" "undecided" "agree" "strongly agree"

\begin{tabular}{|l|l|}
\hline 1. & $\begin{array}{l}\text { I would prefer my teacher using Arabic in my English class when } \\
\text { explaining new vocabulary. }\end{array}$ \\
\hline 2. & I would prefer my teacher using some Arabic in my English class \\
\hline
\end{tabular}




\begin{tabular}{|c|c|}
\hline & when she gives instructions to the class. \\
\hline 3. & $\begin{array}{l}\text { I would prefer my teacher using some Arabic in my English class } \\
\text { when explaining a new grammar topic. }\end{array}$ \\
\hline 4. & $\begin{array}{l}\text { I would prefer my teacher allowing me to use Arabic in my English class during the reading } \\
\text { comprehension tasks. }\end{array}$ \\
\hline 5. & $\begin{array}{l}\text { I would prefer my teacher allowing me to use Arabic in my English class while discussing errors I } \\
\text { make in the writing assignments. }\end{array}$ \\
\hline 6. & $\begin{array}{l}\text { I would prefer my teacher allowing me to use Arabic in my English class during the listening } \\
\text { comprehension tasks. }\end{array}$ \\
\hline 7. & I use Arabic when I have to explain something related to my English lessons to my classmates. \\
\hline 8. & $\begin{array}{l}\text { I use Arabic during my English classroom when I exchange some personal information with my } \\
\text { classmates. }\end{array}$ \\
\hline 9. & I use Arabic during group work tasks since it helps us finish the task faster. \\
\hline
\end{tabular}

\section{Appendix B}

\section{Questions for Semi-Structured Interviews}

1. Please, state your age, gender, and years of experience.

2. What is your opinion on monolingual and bilingual teaching approaches? Please, explain.

3. Which of them do you prefer to use in EFL classroom? Why?

4. When and in what situations (if you do) do you use L1 (Arabic) in the classroom? If you do not use, please, explain why do you prefer monolingual/bilingual approach?

5. Which approach do your students prefer more, bilingual or monolingual? How would you explain their preference?

6. What changes would you do to the EFL teaching methodologies if you have a chance?

7. What is your opinion on the growing demand of using L1 in EFL classrooms?

8. What would you recommend teachers who oppose using L1 in the classroom? (Optional question: if the participant supports bilingual approach).Appendix $\mathbf{C}$

Case Processing Summary

\section{Reliability of the Scale}

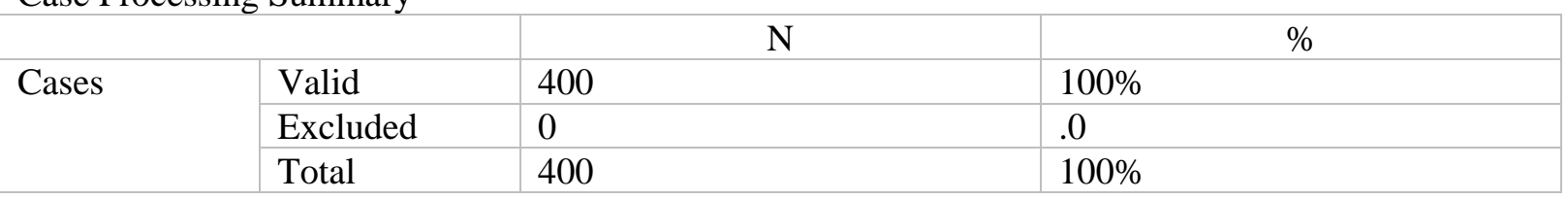

Reliability Statistics

\begin{tabular}{|l|l} 
Cronbach's Alpha & N of Items \\
\hline
\end{tabular}

$.834 \quad 10$

